\title{
Researches regarding the influence of the some technological elements on water use efficiency in maize from Crisurilor Plain
}

\author{
Ioana Borza - Cristian Domuța \\ University of Oradea, Faculty of Environmental Protection, Oradea, Romania \\ borzaioanamarial@yahoo.com
}

SUMMARY

The paper is based on the researches carried out on the preluvosoil in Agricultural Research and Development Station Oradea, Crisurilor Plain and the influence of the hybrid, plant density, crop rotation, nutrient supply, weeds and irrigation on water use efficiency were studied.

Choosing of the hybrid with the best water use efficiency is very important because a hybrid from 500-600 FAO group (Fundulea 376) in unirrigated conditions and a hybrid from FAO group over 600 (Fundulea 365) obtained the biggest water use efficiency; the hybrid Fundulea

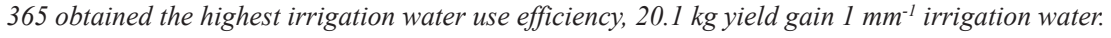

One of the most known hybrid in the area is Turda super and the highest water use efficiency was obtained using the plant density of 55000 plants/ha in unirrigated variant and 70000 plants/ha in irrigated variant. The highest irrigation water use efficiency, $20.7 \mathrm{~kg}$ yield gain

$1 \mathrm{~mm}^{-1}$, was obtained at 70000 plants $\mathrm{ha}^{-1}$.

In maize monoculture was obtained the lowest values of the water use efficiency in unirrigated and irrigated variant: in the wheat-maize crop rotation the values were higher than in maize monoculture and in the wheat-maize-soybean were registered the highest values. The same situation was registered regarding the irrigation water use efficiency.

Farm manure $\left(30 t \mathrm{ha}^{-1}\right)$ and especially manure $\left(30 \mathrm{th} \mathrm{h}^{-1}\right)+$ chemical fertilizers $\left(N_{90} P_{45}\right)$ determined a higher values of the water use efficiency in comparison with the control. In the variant with organic + mineral fertilization was registered the higher value (19.4 $\mathrm{kg}$ yield gain $\mathrm{mm}^{-1}$ ) of the irrigation water use efficiency.

Water use efficiency was much lower in the variant with weeds in comparison with the variant without the weeds; the differences were of $69 \%$ in unirrigated variant and of $64 \%$ in irrigated variant, very significant statistically. Irrigation water use efficiency from variant with weeds was lower than the value registered in the variant without weeds; the difference (68\%) was very significant statistically.

In average in period 1976-2012, the irrigation determined the increasing in water use efficiency with $22 \%, 19.4 \mathrm{~kg} \mathrm{~mm}^{-1} \mathrm{vs} .15 .8 \mathrm{~kg} \mathrm{~mm}$, but not in all the years caused the irrigation increasing in water use efficiency in comparison with unirrigated maize.

The results research emphasized the need of the optimization for technology elements studied and a better water use efficiency will be obtained.

Keywords: hybrid, plants density, crop rotation, weeds, fertilization, water use efficiency

\section{INTRODUCTION}

A prime concern in cultivating crops has always been water availability (Sinclaire et al., 1984).

Researches regarding the water use efficiency of the crops from Crișurilor Plain began in 1973 by Stepănescu E. in the field for water balance research from Girişu de Criş. Starting with 1976, the researches were continued in Oradea (Domuţa, 2009a,b).

Domuţa C. in his $\mathrm{PhD}$ thesis "Contributions to the establishment of water consumption of the main crops from Crişurilor Plain" presented a synthesis of the results obtained during the period 1987-1993; in the same paper he studied the influence of the irrigation rate reduce on water use efficiency (Domuţa, 1995).

In the period 2001-2004, Ioana Borza carried out extensive research on the use of water by maize culture, completed the $\mathrm{PhD}$ thesis "Researches regarding the influence of some phytotechnycal measures on water use efficiency in maize in the Crişurilor Plain conditions" (Borza, 2006, 2007, 2008, 2009a,b, 2010b).

Cr. Domuţa in 2010 in the $\mathrm{PhD}$ thesis "Research regarding the irrigation influence on maize, soybean and sugarbeet in the Crişurilor Plain", presents the results of research in the period 2007-2009 relating to the effect of the irrigation suspending on water use efficiency and irrigation water use efficiency in maize, soybean and sugarbeet (Domuţa, 2010, 2011; Domuţa and Domuţa, 2010).
Maria Şandor (project director), C. Domuţa (scientific director) in the project, "The study of the relationship from soil-water-plant-atmosphere system on the soil affected by excess and deficit of moisture in NorthWestern Romania regarding to improve the quantity and quality of the yields" studied the influence of crop rotation, soil tillage, crop rotation and the water regime, organic and mineral fertilisation, amendments, crop protection against diseases, pests and weeds, on the water use efficiency in wheat and maize.

\section{MATERIAL AND METHODS}

The research is based on the results obtained in the field water balance in the soil from Oradea, as well as on the results obtained in stationary or experiences with crop protection products against diseases, pests and weeds.

The preluvosoil from the research field is a low acidic, with a low humus content and with a medium phosphorus and potassium content. The wilting point and the field capacity values were medium. The soil texture determined an easily available water content of $2 / 3$ from the difference between the field capaciy and the wilting point. (Brejea, 2009; Brejea and Domuţa, 2011; Răducu et al., 2012). The irrigation depth in sugarbeet in this area is of $0-75 \mathrm{~cm}$ (Grumeza and Klepş, 2005). 
The soil's moisture was determined twice in a month; when the value of the soil water reserve on the 0-75 cm depth decreased to easily available water content, the irrigation was used in order to assure an optimum water consumption. As a consequence, the optimum water consumption was registered in the irrigation variant. The plants water consumption was established using the method of the soil water balance.

The two elements necessary for the calculation of the water use efficiency (production and water consumption) and the calculation of the irrigation water use efficiency (yield gain, irrigation rate) were obtained in compliance with the technical experimental protocol.

The significant differences between the yield registered in the irrigated and unirrigated variants were determined using the variance analysis method (Domuţa, 2006).

\section{RESULTS AND DISCUSSION}

\section{Hybrid influence on water use efficiency}

Six hybrids from all the FAO groups were studied between 2008-2012 both in unirrigated conditions and in irrigated conditions

In unirrigated conditions, the lowest water use efficiency, $15.8 \mathrm{~kg} \mathrm{~mm}^{-1}$, was registered in the hybrid with the shortest vegetation period, Ciclon; the highest water use efficiency was registered in the hybrid from 500-600 FAO group, Fundulea $376,17.2 \mathrm{~kg} \mathrm{~mm}^{-1}$ (table 1).

In the irrigated variants, the lowest water use efficiency was registered in Ciclon, too, but the highest value was registered in the hybrid with the longest vegetation period, Fundulea $365,18.5 \mathrm{~kg} \mathrm{~mm}^{-1}$; in the irrigated hybrid Ciclon and Turda super (FAO group 200-300) the water use efficiency values were lower than the values registered in the unirrigated variants; in average on the irrigated hybrids, the water use efficiency increased in comparison with the unirrigated hybrids, $16.7 \mathrm{vs} .16 .5 \mathrm{~kg} \mathrm{~mm}^{-1}$. Regarding the statistically significant of the differences in comparison with the hybrid Ciclon, the difference was statistically confirmed only in Fundulea 376 in unirrigated conditions; in irrigated conditions, the hybrids from FAO groups over 300 had the differences statistically assured in comparison with the hybrid Ciclon (table 1).

Irrigation water use efficiency had the lowest values in the hybrids from 100-200 and 200-300 FAO group, Ciclon $10.0 \mathrm{~kg}$ yield gain $\mathrm{mm}^{-1}$, Turda super, $11.4 \mathrm{~kg}$ yield gain $\mathrm{mm}^{-1}$. In the hybrids from other FAO groups, the irrigation water use efficiency was very significant statistically higher than the irrigation water use efficiency determined in Ciclon; the highest value of the irrigation water use efficieny was registered in Fundulea 365, (FAO group over 600), $20.1 \mathrm{~kg}$ yield gain (table 1).

Hybrid influence on water use efficiency (WUE) and irrigation water use efficiency (IWUE) in maize (Oradea, 2008-2012)

\begin{tabular}{|c|c|c|c|c|c|c|c|}
\hline \multirow{3}{*}{ FAO Group } & \multirow{3}{*}{ Hybrid } & \multicolumn{4}{|c|}{ WUE } & \multicolumn{2}{|c|}{ IWUE } \\
\hline & & \multicolumn{2}{|c|}{ Unirrigated } & \multicolumn{2}{|c|}{ Irrigated } & \multirow{2}{*}{$\begin{array}{c}\mathrm{Kg} \text { yield } \\
\left(\text { gain } \mathrm{mm}^{-1}\right)^{3}\end{array}$} & \multirow{2}{*}{$(\%)$} \\
\hline & & $\left(\mathrm{kg} \mathrm{mm}^{-1}\right)^{1}$ & $(\%)$ & $\left(\mathrm{kg} \mathrm{mm}^{-1}\right)^{2}$ & $(\%)$ & & \\
\hline $100-200$ & Ciclon & $15.8^{\mathrm{Ct}}$ & 100 & $14.6^{\mathrm{Ct}}$ & 100 & $10.0^{\mathrm{Ct}}$ & 100 \\
\hline $200-300$ & Turda super & $16.3^{-}$ & 104 & $15.5^{-}$ & 107 & $11.4^{-}$ & 114 \\
\hline $300-400$ & Saturn & $16.1^{\circ}$ & 102 & $16.7^{* *}$ & 115 & $16.0^{* * * *}$ & 160 \\
\hline $400-500$ & ZP 335 & $16.6^{\circ}$ & 105 & $17.4^{* *}$ & 120 & $17.6^{* * *}$ & 176 \\
\hline $500-600$ & Fundulea 376 & $17.2^{*}$ & 109 & $18.0^{* * * *}$ & 124 & $18.2^{* * *}$ & 182 \\
\hline Over 600 & Fundulea 365 & $16.9^{-}$ & 107 & $18.2^{* * * *}$ & 125 & $20.1^{* * *}$ & 201 \\
\hline Average & & 16.5 & 100 & 16.7 & 101 & 15.6 & 156 \\
\hline
\end{tabular}

\section{Effect of plants density on water use efficiency}

An experiment with 5 plant density was made in 2008-2012 in unirrigated and irrigated conditions. In average on the studied period in the variant with 25000 plants ha-1 ${ }^{-1}$ was registered the lowest values of the water use efficiency, $13.9 \mathrm{~kg} \mathrm{~mm}^{-1}$ in unirrigated variant and $13.6 \mathrm{~kg} \mathrm{~mm}^{-1}$ in irrigated variant. In comparison with this variant, in the variant with 55000 plants $^{-1} \mathrm{a}^{-1}$ was registered a difference very significant statistically and in the variants with 70000 plants ha ${ }^{-1}$ and $40000^{-1}$ plants $\mathrm{ha}^{-1}$ the differences were distingue significant statistically in unirrigated conditions. The irrigation determined the higher values of the water use efficiency in comparison with unirrigated variant in the plots with 70000 and 85000 plants ha ${ }^{-1}$; the highest value of the water use efficiency in the irrigated variants was registered in the variant with 70000 plants ha' ${ }^{-1}, 18.8 \mathrm{~kg} \mathrm{~mm}^{-1}$ (table 2).
Irrigation water use efficiency increased very significant statistically in comparison with the plant density of 25000 plants ha ${ }^{-1}$ in the all variants studied. The highest value $20.7 \mathrm{~kg} \mathrm{~mm}^{-1}$ was registered in the variant with 70000 plants ha-1 (table 2).

\section{Crop rotation influence on water use efficiency}

The lowest values of the water use efficiency, $14.4 \mathrm{~kg}$ $\mathrm{mm}^{-1}$ and $14.5 \mathrm{~kg} \mathrm{~mm}^{-1}$, were registered in maize monoculture. In comparison with this variant, in wheatmaize crop rotation the values of the water use efficiency were significantly statistically higher. The highest values of the water use efficiency were registered in the wheat-maize-soybean crop rotation, $15.9 \mathrm{~kg} \mathrm{~mm}^{-1}$ and $16.0 \mathrm{~kg} \mathrm{~mm}^{-1}$ (table 3). 
Plant density influence on water use efficiency (WUE) and irrigation water use efficiency (IWUE) in maize (Oradea, 2008-2012)

\begin{tabular}{|c|c|c|c|c|c|c|}
\hline \multirow{3}{*}{ Plant density ha ${ }^{-1}$} & \multicolumn{4}{|c|}{ WUE } & \multicolumn{2}{|c|}{ IWUE } \\
\hline & \multicolumn{2}{|c|}{ Unirrigated } & \multicolumn{2}{|c|}{ Irrigated } & \multirow{2}{*}{$\begin{array}{c}\text { Kg yield } \\
\left(\text { gain mm }{ }^{-1}\right)^{3}\end{array}$} & \multirow{2}{*}{$(\%)$} \\
\hline & $\left(\mathrm{kg} \mathrm{mm}^{-1}\right)^{1}$ & $(\%)$ & $\left(\mathrm{kg} \mathrm{mm}^{-1}\right)^{2}$ & $(\%)$ & & \\
\hline 25000 & $13.9^{\mathrm{Ct}}$ & 100 & $13.6^{\mathrm{Ct}}$ & 100 & $10.9^{\mathrm{Ct}}$ & 100 \\
\hline 40000 & $15.6^{* *}$ & 112 & $15.4^{*}$ & 113 & $13.9^{* * * *}$ & 127 \\
\hline 55000 & $18.8^{* * *}$ & 135 & $17.6^{* * *}$ & 129 & $14.3^{* * *}$ & 131 \\
\hline 70000 & $16.6^{* *}$ & 119 & $18.8^{* * *}$ & 138 & $20.7^{* * *}$ & 190 \\
\hline 85000 & $14.6^{-}$ & 105 & $16.2^{* *}$ & 119 & $18.4^{* * *}$ & 169 \\
\hline
\end{tabular}

${ }^{1} \mathrm{LSD}_{5 \%}=0.9, \mathrm{LSD}_{1 \%}=1.7, \mathrm{LSD}_{0.1 \%}=3.1 ;{ }^{2} \mathrm{LSD}_{5 \%}=1.1, \mathrm{LSD}_{1 \%}=1.9, \mathrm{LSD}_{0.1 \%}=3.3 ;{ }^{3} \mathrm{LSD}_{5 \%}=2.1, \mathrm{LSD}_{1 \%}=3.7, \mathrm{LSD}_{0.1 \%}=6.1$

Table 3 .

Crop rotation influence on water use efficiency (WUE) and irrigation water use efficiency (IWUE) in maize (Oradea, 2008-2012)

\begin{tabular}{|c|c|c|c|c|c|c|}
\hline \multirow{3}{*}{ Crop rotation } & \multicolumn{4}{|c|}{ WUE } & \multicolumn{2}{|c|}{ IWUE } \\
\hline & \multicolumn{2}{|c|}{ Unirrigated } & \multicolumn{2}{|c|}{ Irrigated } & \multirow{2}{*}{$\left(\mathrm{kg} \mathrm{mm}^{-1}\right)^{3}$} & \multirow{2}{*}{$(\%)$} \\
\hline & $\left(\mathrm{kg} \mathrm{mm}^{-1}\right)^{1}$ & $(\%)$ & $\left(\mathrm{kg} \mathrm{mm}^{-1}\right)^{2}$ & $(\%)$ & & \\
\hline 2. Wheat-maize & $15.2^{*}$ & 106 & $15.3^{*}$ & 105 & $15.7^{*}$ & 102.6 \\
\hline 3. Wheat-maize-soybean & $15.9 * *$ & 110 & $16.0^{* *}$ & 110 & $18.4^{* * *}$ & 120.3 \\
\hline Average & 15.2 & 100 & 16.0 & 105 & 16.5 & - \\
\hline
\end{tabular}

${ }^{1} \mathrm{LSD}_{5 \%}=0.7, \mathrm{LSD}_{1 \%}=1.4, \mathrm{LSD}_{0.1 \%}=2.0 ;{ }^{2} \mathrm{LSD}_{5 \%}=0.6, \mathrm{LSD}_{1 \%}=1.2, \mathrm{LSD}_{0.1 \%}=1.9 ;{ }^{3} \mathrm{LSD}_{5 \%}=1.3, \mathrm{LSD}_{1 \%}=3.2, \mathrm{LSD}_{0.1 \%}=3.0$

Irrigation water use efficiency had the lowest value in maize monoculture, $1,53 \mathrm{~kg}$ yield gain $\mathrm{mm}^{-1}$ irrigation water used. In the wheat-maize crop rotation a difference significant statistically was registered $\left(1.4 \mathrm{~kg} \mathrm{~mm}^{-1}\right)$. In the variant with wheat-maize-soybean, the difference $\left(3.1 \mathrm{~kg} \mathrm{~mm}^{-1}\right)$ was very significant statistically (table 3$)$.

\section{Influence of the nutrient supply on water use efficiency}

The use of the farm manure, $30 \mathrm{tha}^{-1}$, determinated a statistically significant increasing of the water use efficiency in unirrigated variant and distingue significant statistically in the irrigated variant. Both in unirrigated conditions and in irrigated conditions, the use of the chemical fertilizer $\left(\mathrm{N}_{90} \mathrm{P}_{45}\right)$ determined statistically very significant increasing of the water use efficiency both in unirrrigated variant $(45 \%)$ and irrigated variant $(52 \%)$. In the all 3 variants, the irrigation determined increasing of the water use efficiency; in average on the studied variants, the relative difference was of $100 \%$ (table 4).

The use of manure $30 \mathrm{tha}^{-1}$ determined statistically very significant increasing (32\%), very of the irrigation water use efficiency; in the variant manure $30 \mathrm{t} \mathrm{ha}^{-1}+$ $\mathrm{N}_{90} \mathrm{P}_{45}$, the difference was higher (83\%), and very significant statistically, too (table 4).

\section{Weeds influence on water use efficiency}

There were annual dicotiledoneus species (Amaranthus retroflexus, Chenopodium album, Solanum nigrum, Polygonum persicaria), perennial dicotiledoneus (Convolvulus arvensis) and annual monocotiledoneus (Echinochloa crus galli) in the experimental area. The irrigation determined increasing of the plants number in Amaanthus retroflexus, Polygonum persicaria and Echinochloa crus galli; the number of Convolvulus arvensis was higher in unirrigated conditions (table 5).

Fertilization influence on irrigation water use efficiency (WUE and irrigation water use efficiency (IWUE) in maize (Oradea, 2008-2012)

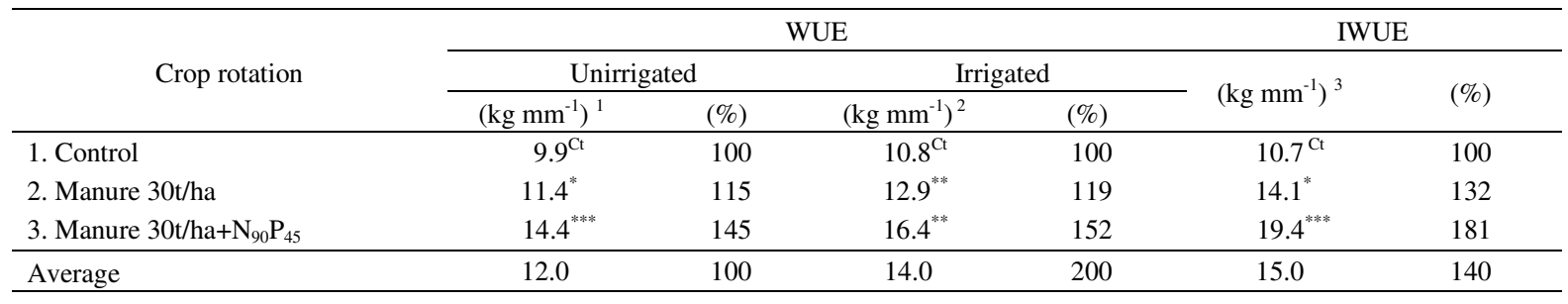

${ }^{1} \operatorname{LSD}_{5 \%}=1.1, \operatorname{LSD}_{1 \%}=1.9, \operatorname{LSD}_{0.1 \%}=3.1 ;{ }^{2} \operatorname{LSD}_{5 \%}=1.0, \operatorname{LSD}_{1 \%}=1.6, \operatorname{LSD}_{0.1 \%}=2.9 ;{ }^{3} \operatorname{LSD}_{5 \%}=1.1, \operatorname{LSD}_{1 \%}=2.3, \mathrm{LSD}_{0.1 \%}=3.7$ 
The influence of the water regime on weeds tickness in maize (Oradea, 2008-2012)

\begin{tabular}{|c|c|c|c|c|}
\hline & Unirrigated & \multirow[t]{2}{*}{ Irrigated } & \multicolumn{2}{|c|}{ Difference } \\
\hline & $\left(\right.$ plants $\left.\mathrm{m}^{-2}\right)$ & & (plants $\mathrm{m}^{-2}$ ) & $(\%)$ \\
\hline 1. Amaranthus retroflexus & 62 & 76 & 14 & 23 \\
\hline 2. Chenopodim album & 11 & 11 & 0 & 0 \\
\hline 3. Solanum nigrum & 5 & 5 & 0 & 0 \\
\hline 4. Polygonum persicaria & 9 & 11 & 2 & 22 \\
\hline 5. Convolvulus arvensis & 4 & 1 & -3 & -75 \\
\hline 6. Echinochloa crus galli & 15 & 19 & 4 & 26 \\
\hline Total & 106 & 120 & 14 & 13 \\
\hline
\end{tabular}

Water use efficiency in the variant with weeds was lower than that of in the variant without weeds. In unirrigated variant the difference was of $69 \%$ and in the irrigated variant the difference was of $64 \%$. Irrigation water use efficiency from the variant with weeds was lower than the irrigation water use efficiency from the variant without weeds with $68 \%$ (table 6).

Weeds influence on water use efficiency (WUE) and irrigation water use efficiency (IWUE) in maize (Oradea, 2008-2012)

\begin{tabular}{|c|c|c|c|c|c|c|}
\hline \multirow{3}{*}{ Variant } & \multicolumn{4}{|c|}{ WUE } & \multicolumn{2}{|c|}{ IWUE } \\
\hline & \multicolumn{2}{|c|}{ Unirrigated } & \multicolumn{2}{|c|}{ Irrigated } & \multirow{2}{*}{$\left(\mathrm{kg} \mathrm{mm}^{-1}\right)^{3}$} & \multirow{2}{*}{$(\%)$} \\
\hline & $\left(\mathrm{kg} \mathrm{mm}^{-1}\right)^{1}$ & $(\%)$ & $\left(\mathrm{kg} \mathrm{mm}^{-1}\right)^{2}$ & $(\%)$ & & \\
\hline With weeeds & 5.2 & 31 & 6.3 & 36 & 7.9 & 42 \\
\hline
\end{tabular}

${ }^{1} \mathrm{LSD}_{5 \%}=1.9, \mathrm{LSD}_{1 \%}=2.8, \mathrm{LSD}_{0.1 \%}=4.5 ;{ }^{2} \mathrm{LSD}_{5 \%}=2.1, \mathrm{LSD}_{1 \%}=3.2, \mathrm{LSD}_{0.1 \%}=5.2 ;{ }^{3} \mathrm{LSD}_{5 \%}=1.9, \mathrm{LSD}_{1 \%}=2.7, \mathrm{LSD}_{0.1 \%}=5.4$

\section{Irrigation influence on water use efficiency}

In average on the period 1976-2012, the irrigation determined a value of the water use efficiency of 19.4 $\mathrm{kg} \mathrm{mm}^{-1}$ bigger with $22 \%$ than conditiothe value $\left(15.8 \mathrm{~kg} \mathrm{~mm}^{-1}\right)$ registered in unirrigated conditions. Across the year, the variation iterval of the differences between water efficiency of the irrigated variant and of the unirrigated variant was between $-86 \%$ and $461 \%$ (table 7).

Table 7.

Irrigation influence on water use efficiency (WUE) in maize (Oradea, 1976-2012)

\begin{tabular}{lcccc}
\hline \multirow{2}{*}{ Variant } & \multicolumn{4}{c}{ WUE } \\
\cline { 2 - 5 } & \multicolumn{2}{c}{ Average } & \multicolumn{2}{c}{ Variation interval } \\
\cline { 2 - 5 } & $\left(\mathrm{kg} \mathrm{mm}^{-1}\right)$ & $(\%)$ & $\left(\mathrm{kg} \mathrm{mm}^{-1}\right)$ & $(\%)$ \\
\hline Unirrigated & 15.8 & 100 & $3.1-24.8$ & 100 \\
Irrigated & 19.4 & 122 & $10.7-25.7$ & $14-561$ \\
\hline
\end{tabular}

\section{CONCLUSIONS}

Some elements of the maize technology were studied regarding their influence on water use efficiency in conditions of the moderate wet area from Oradea, Crişurilor Plain.

The choice of the hybrid with the best water use efficiency is very important because a hybrid from 500-600 FAO group (Fundulea 376) in unirrigated conditions and a hybrid from FAO group over 600
(Fundulea 365) obtained the highest water use efficiency; the hybrid Fundulea 365 obtained the highest irrigation water use efficiency, $20.1 \mathrm{~kg}$ yield gain $1 \mathrm{~mm}^{-1}$ irrigation water.

One of the most known hybrid from area is Turda super and the highest water use efficiency was obtained using the plants density of 55000 plants ha $^{-1}$ in unirrigated variant and of 70000 plants ha ${ }^{-1}$ in irrigated variant. The highest irrigation water use efficiency, $20.7 \mathrm{~kg}$ yield gain $1 \mathrm{~mm}^{-1}$, was obtained at 70000 plants ha-1.

The lowest values of the water use efficiency was obtained in maize monoculture in unirrigated and irrigated variant: in the wheat-maize crop rotation the values were higher than in maize monocrop and in the wheatmaize-soybean rotation were registered the highest values. The same situation was registered regarding the irrigation water use efficiency.

Farm manure $\left(30 \mathrm{t} \mathrm{ha}^{-1}\right)$ and especially manure $\left(30 \mathrm{t} \mathrm{ha}^{-1}\right)+$ chemical fertilizers $\left(\mathrm{N}_{90} \mathrm{P}_{45}\right)$ determined higher values of the water use efficiency in comparison with the control. In the variant with organic + mineral fertilization the highest value (19.4 $\mathrm{kg}$ yield gain $\mathrm{mm}^{-1}$ ) of the irrigation water use efficiency was registered.

Water use efficiency was much lower in the variant with weeds in comparison with the variant without the weeds; the differences were of $69 \%$ in unirrigated variant and of $64 \%$ in irrigated variant, are very significant statistically. Irrigation water use efficiency from variant with weeds was lower than the value registered in the variant without weeds; the difference $(68 \%)$ was very significant statistically. 
In average in period 1976-2012, the irrigation determined the increasing of the water use efficiency with $22 \%, 19.4 \mathrm{~kg} \mathrm{~mm}^{-1}$ vs. $15.8 \mathrm{~kg} \mathrm{~mm}^{-1}$ but not in all the years, the irrigation determined increasing in water use efficiency in comparison with unirrigated maize.

The results research emphasized the need of the optimization for technology elements studied and a better water use efficiency will be obtained.

\section{REFERENCES}

Borza, I. M. (2006): Cercetări privind influenţa unor măsuri fitotehnice asupra eficienţei valorificării apei de către cultura porumbului în condiţiile Câmpiei Crişurilor. Teză de doctorat Universitatea de Ştiinţe Agricole şi Medicină Veterinară. Cluj-Napoca. 35-70.

Borza, I. M. (2007): Valorificarea apei de către cultura porumbului din Câmpia Crişurilor. Editura Universităţii Oradea. 195-208.

Borza, I. M. (2008): Researches regarding the influence of the plant density on yield and water use efficiency in maize crop from Crisurilor Plain. Analele Universităţii Oradea Fascicula Protecţia Mediului. 13. 13: 17-25.

Borza, I. M. (2009): Hybrid influence on water use efficiency in unirrigated and irrigated maize in the Crişurilor Plain conditions. Bulletin of University of Agricultural Sciences and Veterinary Medicine Cluj Napoca. Agriculture. 66. 1: 273-279.

Borza, I. M. et al. (2009): Water use efficiency under the weeds influence in unirrigated and irrigated maize from Crişurilor Plain. Bulletin of University of Agricultural Sciences and Veterinary Medicine Cluj Napoca. Agriculture. 66. 1: 556.

Borza, I. M.-Alina, Şt. S. (2010): Fitotehnie. Editura Universităţii Oradea. 52-84.

Borza, I. M.-Domuţa, C.-Şandor, M.-Domuţa, C.-Brejea, R.-Vuşcan, A.-Jurca, A. (2010): Researches regarding the irrigation influence on water use efficiency in potato in the Crişurilor Plain conditions. Research Journal of Agricultural Science. Timisoara. 42. 1: 1688, 22-26.

Brejea, R. (2009): Tehnologii de protecţie sau refacere a solurilor. Editura Universităţii din Oradea. 25-46.

Brejea, R.-Domuța, C. (2011): Practicum de pedologie. Editura Universității Oradea. 37-65.
Domuţa, C. (1995): Contribuţii la stabilirea consumului de apă al principalelor culturi din Câmpia Crişurilor. Teză de doctorat ASAS „Gheorghe Ionescu Şişeşti” București. 115-181.

Domuţa, C. (2006): Tehnică experimentală. Editura Universităţii din Oradea. 112-150.

Domuţa, C. 2009, Irigarea culturilor. Editura Universităţii din Oradea. 59-78.

Domuţa, C. (coord.) (2009): Irigaţiile în Câmpia Crişurilor. Editura Universităţii din Oradea. 87-95.

Domuţa, C. et al. (2012): Irigarea culturilor în Câmpia Crişurilor. Editura Universităţii din Oradea. 56-78.

Domuţa, C. (2010): Cercetări privind influenţa irigaţiei asupra culturilor de porumb, soia şi sfeclă de zahăr în condiţiile Câmpiei Crişurilor. Teză de doctorat Universitatea de Ştiinţe Agricole şi Medicină Veterinară Cluj-Napoca. 36-58.

Domuţa, Cr.-Domuţa C. (2010): Irigarea porumbului în Câmpia Crişurilor. Editura Universității din Oradea. 88-120.

Domuţa, C. (2011): Subasigurarea cu apă a porumbului, soiei şi sfeclei de zahăr din Câmpia Crișurilor. Editura Universității din Oradea. 57-84.

Grumeza, N.-Kleps, Cr. (2005): Amenajările de irigaţii din România. Ed. Ceres Bucureşti. 151-158.

Răducu, D.-Martini, A.-Pagliai, M.-Vignozzi, N.-Surdu I.-Ipatie, J. (2012): Micromorphology as a method of assessing the mountain soil sensitivity in order to elaborate the meliorative technology friendly to environment and biodiversity. Analele Universităţii din Craiova. Agricultură-Montanologie-Cadastru. Lucrări Ştiinţifice. 42: 23-29.

Sinclair, T. R.-Tanner, C. B.-Bennett, J. M. (1984): Water-use efficiency in crop production. BioScience. 34. 1: 15-20. 
